\title{
INDEPENDENT AUDITING OF PUBLIC EXPENDITURE AS A TOOL TO IMPROVE THE STATE FINANCIAL CONTROL
}

\author{
AUDITORÍA INDEPENDIENTE DEL GASTO PÚBLICO COMO HERRAMIENTA PARA \\ MEJORAR EL CONTROL FINANCIERO DEL ESTADO
}

\section{AUDITORIA INDEPENDENTE DAS DESPESAS PÚBLICAS COMO FERRAMENTA PARA MELHORAR O CONTROLE FINANCEIRO DO ESTADO}

Vera Batova

Penza State Technological University - Russia Andrey Volkov
Penza state technological University - Russia Lyudmila Krugliak Institute of Lawand National Security - Russia

Andrey Spiridonov Institute of Economics and Law,Academy of Labor and Social Relations - Russia

Resumo: O controle financeiro estatal (SFC) é parte integrante da administração pública. Seu principal objetivo é identificar desvios dos padrões, violações dos princípios de legalidade, eficiência e economia de recursos o mais cedo possível. Isso permite a adoção oportuna de medidas corretivas e, em alguns casos, reparação financeira e prestação de contas aos autores, além de impedir essas violações no futuro. No entanto, se o controle interno for realizado pelos funcionários, diretamente subordinado ao chefe da organização controlada, não haverá questão de objetividade. Nesse sentido, os autores propõem usar a experiência e as habilidades profissionais dos auditores independentes na auditoria da implementação do orçamento.

Palavras-chave: Controle financeiro do Estado; Legislação orçamentária; Controle financeiro externo e interno. 
Abstract: State financial control (SFC) is an integral part of public administration. Its main goal is to identify deviations from standards, violations of the principles of legality, efficiency and resource saving as early as possible. This allows timely adoption of remedial measures, and, in some cases, financial reparation and accountability for perpetrators, as well as preventing such violations in the future. However, if the internal control is carried out by employees, directly subordinate to the head of controlled organization, there can be no question of objectivity. In this regard, the authors propose to use the experience and professional skills of independent auditors in auditing budget implementation.

Key words: State financial control; Budget legislation; External and internal financial control.

Resumen: El control financiero estatal (SFC) es una parte integral de la administración pública. Su objetivo principal es identificar las desviaciones de las normas, las violaciones de los principios de legalidad, eficiencia y ahorro de recursos lo antes posible. Esto permite la adopción oportuna de medidas correctivas y, en algunos casos, la reparación financiera y la rendición de cuentas de los perpetradores, además de prevenir tales violaciones en el futuro. Sin embargo, si el control interno lo llevan a cabo los empleados, directamente subordinados al jefe de la organización controlada, no puede haber objetividad. En este sentido, los autores proponen utilizar la experiencia y las habilidades profesionales de los auditores independientes en la implementación del presupuesto de auditoría.

Palabras clave: Control financiero estatal; Legislación presupuestaria; Control financiero externo e interno.

\section{Introduction}

At present, much attention is paid to the implementation of an effective SFC mechanism in Russia. This is primarily due to the fact that the market economy and the State federated structure create additional governance and control problems at federal, regional and local levels.

In this regard, the priority tasks of state financial control can be as follows (The Budget Code of the Russian Federation of July 31, 1998):

- identification of the actual state of affairs;

- comparison of the final result with the intended goals;

- assessment of the current situation and the choice of corrective measures if necessary.

State financial control in the Russian Federation is carried out in the framework of budget legislation. All the actions in this field are regulated by the Budget Code of the Russian 
Federation, the Federal Laws "On the Budget Classification of the Russian Federation", "On Accounting", the federal budget for the corresponding year and other federal laws.

Considering SFC as a function of public financial management, it should be noted that this function is to some extent carried out by all authorities. In general terms, the structure of the SFC bodies is as follows (The Budget Code of the Russian Federation of July 31, 1998):

a) Legislative authorities:

-Accounting Chamber of the Russian Federation;

- Audit chambers of the constituent entities of the Russian Federation;

- Accounts chambers of municipal bodies;

b) Presidential control institutions:

- Presidential Control Directorate;

- Federal Service for Financial Monitoring;

c) Control institutions of the Government of the Russian Federation:

- Federal Customs Service;

- The Ministry of Finance of the Russian Federation (Federal Treasury, Federal Tax Service);

d) Control institutions of organizations-beneficiaries of budgetary asssets:

- monitoring bodies of ministries and departments;

- supervisory authorities of structural units of constituent entities of the Russian Federation;

- Supervisory authorities of structural units of municipal entities;

e) The Central Bank of the Russian Federation.

The Budget Code of the Russian Federation divides the State (municipal) financial control into external and internal, preliminary and follow-up. External control is carried out by the Accounting Chamber of the Russian Federation, control and accounting bodies of the constituent entities of the Russian Federation and municipalities. Internal control is carried out by the main managers of budgetary funds and the Federal Treasury (The Budget Code of the Russian Federation of July 31, 1998).

The Accounting Chamber of the Russian Federation holds a special place in the financial control system. Its activities are regulated by the Federal Law "On the Accounting Chamber of the Russian Federation". It was created to enhance the Federal Assembly of the Russian Federation control over the timely execution of federal budget and federal extrabudgetary funds in terms of volume, structure and specific purpose. The Accounting Chamber 
monitoring actions are focused on the federal budget funds, federal extra-budgetary funds and federal property (Federal Law No. 4-FZ of January 14, 1995).

The organizations subject to Accounting Chamber control include:

1) all public authorities (including their apparatus) and institutions, federal extrabudgetary funds;

2) local governments, enterprises, organizations, banks, insurance companies and other financial and credit institutions, their unions, associations, regardless of types and forms of ownership, if they receive or use funds from the federal budget or use the federal property, or manage it, and also have tax, customs and other benefits and advantages provided by federal law or federal government bodies;

3) public associations, non-governmental funds and other non-governmental nonprofit organizations, that receive or use funds from the federal budget, use or manage the federal property, or have tax, customs and other benefits and advantages provided by federal law or federal government bodies.

The Law of the Russian Federation "On the Accounting Chamber of the Russian Federation" sets out that this state body works toward the following goals (Federal Law No. 4FZ of January 14, 1995):

- Organization and implementation of control over the timely execution of the federal budget and the budgets of federal extra-budgetary funds in terms of volume, structure and specific purpose;

- Measuring effectiveness and relevance of public expenditure and federal property use;

- Assessment of the appropriateness of income and expenditure projects of the federal budget;

- Financial due diligence of draft federal laws and federal regulatory legal acts;

- Analysis of identified deviations from established budget indicators and preparation of proposals for their elimination;

- Control over the legality and timeliness of budgetary flows in the Central Bank of the Russian Federation, authorized banks and other financial and credit institutions; - Regular submission of information on the progress of budget execution and the results of control measures to the Chambers of the Federal Assembly of the Russian Federation. 
The auditors have the same objectives verifying the correctness of spending the federal budget funds. In this case, the main goal is to assess the effectiveness of their use.

\section{Methods}

The data from the official websites of Russian public authorities, TAdviser.ru website, regulatory documents, expert assessments of state financial control development in Russia, scientific articles in professional journals, materials of the audit of financial and business activities of a number of enterprises have been used.

\section{Results}

Strengthened corruption-fighting efforts of Russian authorities revealed the increased number of reported crimes and crimes under investigation involving corruption. As a rule, these are facts of embezzlement, misappropriation, misuse and inefficient use of budget resources.

In almost all cases, budget recipients create schemes of funds withdrawal and misappropriation to the detriment of interests of the State.

Recently, federal inspectors have revealed corruption offenses in Chelyabinsk region where the major repair of a sports facility was done. The customer - recipient of funds from the federal budget - contracted with a contractor who did not even simulated the construction and installation work specified by the contract, but, nevertheless, received the entire sum. When inspectors of works discovered this violation, the head of the contracting company was already abroad.

This embezzlement of public funds is impossible without the involvement of chief executives and affiliated persons (often the members of their families).

The main feature of such situations is that the use of state budgetary funds was controlled inefficiently. In accordance with the Budget Code, the management of organizations and enterprises receiving budget provisions must ensure strict control over their effective use and take measures to prevent violations of budget discipline. But the control activities are often organized in such a way that they do not run counter to the management's ownership interests.

The actions of property relations unit of the Russian Ministry of Defense, headed by Mrs. Ye.N.Vasilyeva, provided an obvious example of public funds misappropriation. 
Violations detected by law enforcement agencies would not have been possible if monitoring activities had been properly organized.

Another case of embezzlement to be noticed took place in one of the largest publishing houses in Europe, which was a branch of a Russian federal unitary enterprise. The new chief executive of the branch caused damage of about 18 million rubles over six months and led the enterprise to bankruptcy. He transferred state assets to an affiliated company, the head of which he was before, redirected cash flows to a company controlled by his son and committed a number of other violations, some of them interested law enforcement agencies. Obviously, there was no internal control in the enterprise. According to the inspectors from parent organization, no violations were found. Later it turned out that the head of the parent organization was a military service colleague of chief executive under his authority.

The situations described above show that, at present, the state financial control system in the Russian Federation requires serious improvement. The lack of a well-functioning mechanism of state financial control negatively affects the entire structure of state power, promotes corruption, which is the most sensitive subject of Russian economy and a clear obstacle to achieving the strategic goals of the country. In our opinion, the principal reasons for the inefficacy of public financial management are the following:

1) Late response to the violations, which allows hiding significant amounts of funds and makes their return difficult, even impossible. It is usually done by allocating funds to affiliated companies, after which it is difficult to track cash flows, since often no document can be found. The schemes are used to transfer assets to off-shore jurisdictions, which also significantly complicates control.

It should be noted that all illegal schemes are not original and, as a rule, have historical analogues.

2) It is difficult to prove the criminal intent of managers in their choice of contractors. Numerous facts of violations in public procurement procedure confirm the imperfection of the current legislation.

This point can be illustrated by the example of an enterprise engaged in water supply and sanitation in the Krasnodar Region. The head of this enterprise leased communal facilities owned by his son's company for several years, which is violation of current law. Prior to their acquisition by son's company, the facilities were on the balance sheet of municipalities that were looking for an organization to transfer them to, since their maintenance was burdensome. They were sold for an amount not exceeding half a million rubles. Then, the acquirer leased the 
facilities to the father's municipal enterprise for 3 million rubles a year. At the same time, the tender was held in accordance with laws on public procurement. Since the facilities were old, , the enterprise annually carried out their major repair according to the documents provided. As a result, the amount of enterprise operating expenses grew, which led to a decrease in profit not exceeding 100 thousand rubles given an annual turnover of billion rubles. Since the enterprise was municipal property, a quarter of its profit should have been transferred to the municipal district budget.

This scheme worked for almost four years, until it was disclosed by independent auditors. In this regard, questions arise about the feasibility of transactions and the effectiveness of municipal control. Sometimes, funds came to the enterprise's accounts a year and a half after they were received from the population. It has been suggested that a part of this money was embezzled by the head of the enterprise and his son, who was registered as an agent collecting fees for water supply and sanitation services.

In addition, water tariffs for the population of this municipal district were higher than those established by the Regional Department of tariffs in the field of housing and communal services. Moreover, these facts were revealed by Department inspectors two years later.

It should be noted that the municipal administration repeatedly attempted to dismiss the head of enterprise in question, but the court reinstated him each time, since the documents did not give evidence against him. Only after the inspection report was issued and transferred to the customer, this manager was fired. However, nothing is known about the damage compensation caused by him to the enterprise.

3) It is difficult to determine the efficiency of resource use. There is no methodology for determining the effectiveness of public spending, the criteria and performance indicators are not defined, since the ultimate goals of projects using budget funds are not always commercial.

Commonly, the results of State-funded projects are social facilities, new weapons, space equipment, sports facilities, etc. As a rule, these are not typical projects; they have unique characteristics, which greatly complicate the calculation of their planned cost. Often this leads to the constant cost increases. Moreover, failure to achieve goals can be easily explained by objective reasons, which are often systemic in nature.

4) The lack of adequate punitive measures for the violators of budget legislation. Responsibility for violations in the field of budget legislation is established by the Budget Code of the Russian Federation where 23 budget violations are described. The Administrative 
Violations Code of the Russian Federation assigns liability for only three of them. Since 2003, criminal liability was introduced for misuse of budgetary funds and state extra-budgetary funds (Article 285.1 and Article 285.2 of the Criminal Code of the Russian Federation). However, in practice, there are very few cases when guilty persons return at least a part of inefficiently spent, misused budget funds.

It can also be noted that "the state financial control in the area of counteracting the money laundering is in unsatisfactory condition today, because, despite all the positive experience in this field, such cases are seldom followed through and are often abandoned (primarily by law enforcement agencies)".

Currently, the Accounting Chamber consists of the chairman, deputy chairman, staff of the chamber and 12 auditors who are elected for 6 years. Each of the auditors controls a separate area of activity.

In 2017, the Accounting Chamber paid special attention to: monitoring the implementation of decrees of the President of the Russian Federation of May 2012; monitoring and control over the development and implementation of priority projects and programs in the main areas of strategic development of the Russian Federation; monitoring the implementation of measures to promote import substitution (Shepelev, 2017).Other priorities in 2017 were the following:

-organization and monitoring of effective targeted use of the federal budget funds and state extra-budgetary funds of the Russian Federation;

-monitoring progress to the achievement of strategic goals of social and economic development of Russian Federation;

-determining the effectiveness of the procedure for the formation, management and disposal of federal and other resources, including for strategic planning purposes, and its compliance with legal acts of the Russian Federation;

-analysis of identified shortcomings and violations in the process of formation, management and disposal of federal and other resources within the authority of the Accounting Chamber, development of proposals for their elimination and improvement of budgetary process as a whole;

-assessment of the effectiveness of tax exemptions and other benefits and advantages, as well as credits provided from the federal budget; 
-assessment of the legality of state guarantees provision or other means to support obligations in transactions concluded by legal entities and individual entrepreneurs at the expense of federal and other resources;

-determining the reliability of budget reporting generated by the persons allocating the federal budget funds and the state extra-budgetary funds and the annual report on the execution of the federal budget, and budgets of state extra-budgetary funds of the Russian Federation.

In 2017, the Accounting Chamber of the Russian Federation held 236 monitoring events and 83 expert and analytical events, which covered 4,841 objects in all the constituent entities of the Russian Federation. During this period, 6455 violations and shortcomings were detected in the use of budget funds amounting to 1,865.6 billion rubles, including 2,078 violations in the formation and execution of the budget amounting to 599 billion rubles.

In 2017, 2,317 violations of the legislation were recorded in state (municipal) procurements and purchases by certain types of legal entities amounting to 118.4 billion rubles.

The volume of misused public funds amounted to 4.7 billion rubles, and the amount of inefficiently spent federal and other resources was 34.8 billion rubles.

In total, an amount of 19.2 billion rubles was recovered in 2017 thanks to the action of Accounting Chamber (Shepelev, 2017).

It has to be noted that the State authorities exercise control over a significant part of public spending in key areas. But the main point is that controlling actions are usually accomplished years after budget transactions and expenditures. Thus, the audit of controlled organizations is retrospective. The main control method is to compare actual and planned indicators (analysis of income and expenses estimates), to identify deviations and their cause.

\section{Discussion}

In our opinion, a significant part of violations can be prevented with the proper organization of internal control.

The internal control system should track all the facts of economic activities of an enterprise. In this regard, the internal control should perform the following functions:

1) to cut across all the management system: from tasking and strategy development to monitoring each operation of acquiring and using any resource or asset, ensuring their safety; 
2) to contribute to the implementation of management decisions, evaluating their legality and efficiency, to show the true situation of the enterprise, to identify and minimize risks (Volkov \& Chernysheva, 2011).

The internal control system should not only evaluate the efficiency of economic activities, but also prevent the illegal operations and negative results of financial transactions. Internal control determines the legality of business operations and their economical feasibility.

Internal financial control is aimed at implementing the following goals:

a) assessing the financial status and effectiveness of financial and economic activities of the enterprise;

b) comparing the actual indicators of public contract with the planned ones;

c) establishing the causes of identified deviations and their elimination;

d) preventing possible violations;

e) verifying the compliance of actual qualitative characteristics of work (services) to the requirements established by regulatory legal acts;

f) ensuring the efficient use of State property;

g) ensuring the targeted use of budget funds.

As noted above, the internal control system is organized by the enterprise management. This is the first and main difference between internal control and other types of control. Moreover, if various monitoring tools are managed by only one person, usually the head of the enterprise, this can dramatically reduce their effectiveness, as evidenced by the examples above.

The internal control of operating activities is necessary to identify criminal schemes and the facts of inefficient use of resources. For example, the municipal enterprise mentioned above paid the expenses for cellular communications not only of the CEO, but of other employees too. The cost of fuel and lubricants of personal vehicles were also covered by the enterprise. It should be noted that under current legislation these expenses should be included in financial results.

The key function of internal control is to develop and submit not only proposals for the elimination of identified violations, but also recommendations for improving management efficiency, developing the enterprise's potential, as well as in an advisory support to the management. Internal control helps identifying the effectiveness of the organization's management system.

It is hard to overestimate the importance of internal control. Its rational organization ensures the property protection, the quality of accounting and the reliability of reporting, as 
well as mobilization of existing production, finance and other resources. It is a part of enterprise management system that serves to ensure a long-term financial stability, and aims to increase company management efficiency (Volkov \& Chernysheva, 2011).

The most important elements of internal control are risk identification, risk analysis, managerial decisions aimed at its elimination, reduction and minimization.

The problem of assessing the risk of abuse is directly related to a reckless negligence both in conducting business in general and in choosing contractors in particular.

Internal control is a management tool that allows for the most efficient implementation of various business processes. Internal control should not only help detect shortcomings and violations in economic transactions, but also prevent their occurrence in the future. And it is important to carry it out continuously, without gaps during the entire reporting period, in full accordance with the approved regulations.

At the same time, today the effectiveness of the internal financial control system in budgetary institutions remains low compared to the internal control in commercial sector. The main reason is that the senior managers of budgetary institutions are reluctant to provide access to control their actions. In private enterprises, the role of internal controller is usually played by owner's trusted person. In budgetary institutions, the internal control system is often formal. Thus, it is necessary to develop measures to increase the effectiveness of internal control in public sphere.

The procedure for implementing internal financial audit is laid out in the Budget Code of the Russian Federation. The executive heads are authorized to conduct it in order to assess the reliability of internal financial control, confirm the reliability of budget reporting and prepare recommendations to improve the efficiency of budget expenditures. Unlike the controller, auditor has the task that does not consist in a simple acknowledgment of transactions legality, but also in drafting of recommendations for enhancing internal financial control.

At the same time, the function of internal control can be transferred to independent consultants (auditors) who determine forms and types of control activities. From an economic point of view, the use of external auditors is advisable if enterprise own resources are insufficient to create and maintain a special control unit or of its cost is higher than the cost of services provided by independent auditors.

Internal financial audit is carried out in compliance with the principles of objectivity and professional competence. The purpose of audits is not just fixing violations of budget 
legislation, inefficient spending, but assessing the degree of reliability of budget procedures in order to prevent misuse and violations.

The internal financial control is applied to the totality of financial and business transactions performed in the system of budget funds administrator in the reporting period (Kotoyan, 2018).

The organization of internal control with the use of external auditors is an important factor in improving the efficiency of budget funds. In this case, the objectivity and reliability of the results is achieved through the main principle of audit: its independence. The employees of the enterprise internal control unit are a priori subordinate to its head, whose managerial decisions they must control, therefore they cannot be independent and objective.

Since the practice of independent auditors is more varied, their controlling toolkit includes more different control methods. Modern internal control systems are often transformed into a risk assessment tool; there is a shift in emphasis from the assessment of individual operations to the assessment of enterprise's risk potential. However, it is necessary to control not only the economic activities, accounting and reporting, but also the audit transactions, events, operations that affect the financial situation of an economic entity, the financial result of its activities and cash flow. Moreover, the effectiveness of control will be higher if it is carried out in the monitoring mode.

The construction of a monitoring system for principal financial indicators can be broken in the following main steps:

1) development of a system of informative reporting indicators for each type of financial control, based on the data of financial and management accounting. This system represents the so-called "primary monitoring database", which is necessary for calculation of the individual analytical absolute and relative financial indicators aggregated for the entire enterprise and characterizing the results of its financial activities;

2) development of a system of general (analytical) indicators reflecting the actual results in achieving the expected quantitative control standards, well aligned with the system of financial indicators. Meanwhile, a reporting records system by each kind of financial control is developed;

3) determination of structure and indicators for the monitoring reports;

4) determination of control periods for each type of financial control and every group of monitored indicators; 
5) establishment of accepted range of indicators deviations from established standards;

6) identifying the main causes of deviations from established standards.

In the process of creating such a system, the algorithms for calculating individual generalizing (analytical) indicators are developed, based on the primary observations and financial analysis methods.

The importance of state financial control is so great that the International NonGovernmental Organization of Supreme Audit Institutions (INGOSAI) has developed a number of auditing standards that are recommended for use by regulatory authorities of different countries to the extent that they are consistent with national legislation. These standards allow to ensure the uniformity of control activities and to achieve more credible results. International audit standards determine the fundamental methods of financial control, contribute to improving the quality of control in accordance with the increased requirements in the field of international audit, and are also aimed at increasing effectiveness of the fight against corruption and financial fraud (primarily by law enforcement agencies).

\section{Findings}

The reasons for the low efficiency of SFC are the following:

- In Russia, state financial control has a retrospective nature. This leads to a late response to violations which allows the perpetrators to hide a significant amount of funds and makes their return difficult, even impossible;

-It is hard to prove criminal intent in senior managers' choice of contractors;

-It is difficult to determine the effectiveness of budget funds use without comprehensive methods of its calculation;

-There are no adequate measures to hold violators accountable in Russian budget legislation.

An important point is the low efficiency of internal control system in budgetary organizations. This can be explained by the reluctance of the heads of these organizations to provide access to control and evaluation of their actions, which affects the personnel selection. In addition, we cannot talk about the complete independence of internal controllers, since they are full-time employees and their wages depend on senior manager decision.

In this regard, it is advisable to engage independent auditors who possess a large kit of modern control tools, and, which is most important, - they must have no links with the audited 
entity. They can work under an outsourcing agreement ensuring the remote access to the information base of the audited entity. Reports will be periodically transmitted to a higher organization, if necessary, with an appendix in the form of video and photo reports, when, for example, construction and installation works are carried out. At the same time, the control in the monitoring mode will be more effective.

At the end of August 2018, it was made public that the Russian control and supervision authorities (CSA) may start using the big data technologies to collect and analyze information about the objects to monitoring. The system has the working name of "digital inspector", the Vedomosti newspaper writes with reference to the action plan for digital state administration a new area of the digital economy (Supervisory authorities will master Big Data, 2019).

It is assumed that the "digital inspector" will collect and analyze data on the objects of supervision and give instructions to human inspectors. Moreover, for each type of state supervision, a set of data necessary for risk assessment will be determined, an informed source reports. According to him, this can be data from state information systems (GIS), company reports in machine-readable form, data from Internet of things sensors and the results of public control.

It is noted that the federal authorities will not have to arm themselves with special software for introducing machine inspection, they should simply upgrade their systems. In turn, regional controllers will take advantage of the revised options for a typical cloud solution for supervision authorities. The provision was approved in April 2018 by the government of Russian Federation. A standard solution should automatically generate registers of the inspected objects and action plans for them, assign risk categories, and interact with other GIS.

By the end of 2018, "Digital Inspector" was used in test mode by Rosprirodnadzorand and Federal Customs Service. The creation of such a technology from scratch is estimated by experts at hundreds of millions rubles, and the time needed to bring it into operation is about two years (Supervisory authorities will master Big Data, 2019).

In our opinion, the use of the experience and professional skills of auditors is more appropriate.

\section{REFERENCES}

1. The Budget Code of the Russian Federation of July 31, 1998 No. 145-FL.

2. Federal Law No. 4-FZ of January 14, 1995 "On the Accounting Chamber of the Russian Federation". 
3. Federal Law No. 6-FZ of February 7, 2011 "On General Principles of Organization and Activities of Control and Audit Bodies of the constituent entities and municipalities of the Russian Federation".

4. Federal Law No. 115-FZ "On Counteracting the Legalization (Laundering) of Criminally Obtained Incomes and the Financing of Terrorism".

5. Russian Government Decree № 714 of 17.07.1995 “On the Approval of the Procedure for control over the targeted use of financial support."

6. Order of the Ministry of Finance of Russia No. 146n of 25.12.2008 "On ensuring activities for the implementation of state financial control".

7. Order of the Ministry of Finance of Russia No. 18n of March 20, 2014 "On the Approval of the administrative regulations for the federal service of financial and budgetary supervision to ensure control function in the financial and budgetary sphere".

8. Order of the Ministry of Economic Development of Russia No. 30 of January 28, 2011 "On the Approval of the procedure for scheduled inspections when placing orders for the supply of goods, works or and services for customers needs".

9. Order of the Ministry of Economic Development of Russia No. 598 of October 26, 2011 "On the Approval of administrative regulations for the fulfillment by the Federal Agency for State Property Management of the state function to control the use of federal property".

10. Decree of the Government of the Russian Federation of May 25, 2016 No. 461 "On the Approval of the Rules for credit organizations and non-credit financial organizations to furnish to the Federal Service for Financial Monitoring the information on the facts of refusal to conduct operations with cash and (or) other property, one of which is foreign or international non-governmental organizations included in the list of foreign and international non-governmental organizations whose activities are considered undesirable in the territory of Russian Federation."

11. Rosfinmonitoring order No. 232 of July 25, 2016 "On placing the decisions of the Interdepartmental Commission for Combating the Financing of Terrorism in the official website of the Federal Service for Financial Monitoring in the information and telecommunication network "Internet".

12. Volkov, A. G., \& Chernysheva, E. N. (2011). Control and audit: a training manual. - M.: Publishing. Center EAOI, 224s.

13. Internet Conference of the Chairman of the Accounting Chamber of the Russian Federation Sergey Stepashin // URL: http://www.garant.ru/interview/10206/.

14. Supervisory authorities will master Big Data. (2019). New STI IT market in Russia from TAdviser,20.9.2019.

15. Kotoyan, M. A. (2018). Problems of financial control in Russia. Scientific community of students of the XXI century. Social sciences: Proceedings of XLVIII International Student Scientific and Practical Conference, 11(47). URL: https://sibac.info/archive/social/11(47).pdf (access data: 10/30/2018). 
16. Shepelev, D. R. (2017). State financial control in Russia: problems and prospects [Text]. Economic science and practice: proceedings of the $\mathrm{V}$ International scientific conference (Chita, April 2017). Chita: Publishing House Young Scientist, 53-57.- URL https://moluch.ru/conf/econ/archive/221/12104/ (accessed: 10/30/2018).

\section{SOBRE OS AUTORES:}

\section{Vera Batova}

Senior lecturer of the "Economicsand management" Department,Penza State Technological University. E-mail: batova.v.n@yandex.ru

(iD) http://orcid.org/0000-0003-0484-0819

\section{Andrey Volkov}

Auditor in the Interregionalconsulting firm "Auditecocons", senior lecturerof the "Economics and management" Department,Penza state technological University. E-mail: volkovange@yandex.ru

iD http://orcid.org/0000-0003-2464-513X

\section{Lyudmila Krugliak}

associate professor of the "Economic security" Department, Institute of Lawand National Security,Russian Presidential Academy of National Economyand Public Administration. Email: lissli@yandex.br

iD http://orcid.org/0000-0002-7041-1679

\section{Andrey Spiridonov}

Associate professor of the "Economics and management" Department,Institute of Economics and Law,Academy of Labor and Social Relations. E-mail: uginvest@gmail.com

D http://orcid.org/0000-0001-9898-5298

\section{Yuliya Safronova}

Russian Presidential Academy of National Economy and Public Administration (RANEPA) Russia,119571, Moscow, Vernadskogo Avenue, 82. E-mail: safronova@mail.ru

(iD http://orcid.org/0000-0002-9500-1895 